\title{
Steroid production from 17a-hydoxypregnenolone and dehydroepiandrosterone by human granulosa cells in vitro
}

\author{
Ruth E. Fowler, N. L. Fox, R. G. Edwards and P. C. Steptoe* \\ Physiological Laboratory, University of Cambridge, and *Oldham and District General Hospital, \\ Oldham, U.K.
}

\begin{abstract}
Summary. Granulosa cells were aspirated 3-4 h before the expected time of ovulation from 10 follicles of 4 patients treated with gonadotrophins: 4 of the follicles were immediately preovulatory. The granulosa cells were cultured for $10 \mathrm{~h}$ with $17 \alpha$-hydroxypregnenolone or dehydroepiandrosterone and samples of medium removed at 3 and $10 \mathrm{~h}$ were assayed for 6 steroids.

Granulosa cells were unable to synthesize androgens from endogenous substrate or undertake conversions via the $\Delta^{5}$ pathway, but cells from all follicles were capable of aromatizing exogenous androgens to oestrogens although this capability was reduced in cells from follicles beginning to luteinize. Granulosa cells from preovulatory follicles synthesized more progesterone from endogenous substrate than cells from follicles which had not begun to luteinize. The results provide further support for the two-cell theory of oestrogen biosynthesis whereby granulosa cells aromatize androgens which are synthesized by the thecal cells in vivo.
\end{abstract}

\section{Introduction}

Little is known about the cellular site of steroid synthesis in the human Graafian follicle. Thecal cells are thought to synthesize androgens and oestrogens from endogenous precursors and granulosa cells are known to produce progesterone after luteinization (Ryan \& Petro, 1966; Channing, 1969; YoungLai, Edwards \& Steptoe, 1972). Granulosa cells aspirated from human Graafian follicles 3-4 h before the expected time of ovulation and cultured in vitro convert pregnenolone to progesterone and $17 \alpha$-hydroxyprogesterone, and aromatize androgen substrates to oestrogen (Fowler, Fox, Edwards, Walters \& Steptoe, 1978a). However, little or no oestradiol-17 $\beta$ is produced if the only exogenous substrate is pregnenolone, suggesting that pregnenolone is not converted to androgens. The present study was to assess the utilization of $\Delta^{5}$ steroids by human granulosa cells cultured in medium containing $17 \alpha$-hydroxypregnenolone $\left(17 \Delta^{5} \mathrm{P}\right)$ or dehydroepiandrosterone (DHA). Granulosa cells were taken from preovulatory follicles stimulated by human chorionic gonadotrophin as in the earlier study, and also from large follicles which had not begun to luteinize.

\section{Patients}

\section{Materials and Methods}

Granulosa cells were aspirated from the follicles of 4 patients treated with gonadotrophins (see Fowler et al., 1978a). The patients were infertile because of tubal occlusion and were undergoing treatment by the removal of oocytes and the reimplantation of embryos (Edwards \& Steptoe, 1975). All the patients were aware of the methods and treatments used and had given their informed consent. As shown in Text-fig. 1, Patients 2, 3 and 4 were given successive injections (i.m.) of human menopausal gonadotrophin (hMG: Pergonal, G. D. Searle \& Co.) from Day 3 of the menstrual cycle, followed by a single injection of 5000 i.u. human chorionic gonadotrophin (hCG: Pregnyl, Organon Ltd) on Days 11 or 12, while Patient 1 was treated with hMG, and human luteinizing hormone (MRC $\mathrm{LH})$. In order to assess the response of the patients to the gonadotrophins, 24-h urine samples were 
collected for several days during and after the treatment. Total oestrogens and pregnanediol were measured by the methods described by Brown, Macleod, MacNaughton, Smith \& Smyth (1968) and Rogers \& Chamberlain (1972), respectively. Urinary LH was assayed by the method of Siddiqui, Jackson \& Craig (1975).

\section{Aspiration of follicles}

Follicles were aspirated 32-33 h after the injection of hCG or LH, i.e. 3-4 h before the expected time of ovulation (Edwards \& Steptoe, 1975). Single cells and large sheets of granulosa cells were obtained from 6 follicles of Patient 1 and from 4 follicles of Patients 2, 3 and 4 . In all the patients, large follicles but no corpora lutea were observed. Six of the 10 Graafian follicles of Patient 1 were aspirated successfully and the appearance of large numbers of small clumps of granulosa cells indicated that the follicles were not immediately preovulatory (Fowler, Edwards, Walters, Chan \& Steptoe, 1978b). Between 6 and 12 Graafian follicles were observed in Patients 2, 3 and 4 but only 4 follicles were used in this study (see Table 1). These follicles were preovulatory with large sheets of cells and viscous follicular fluid (Fowler et al., 1978b). The cells were separated from the follicular fluid by centrifugation and the latter was stored at $-20^{\circ} \mathrm{C}$ until assay. If sufficient was available the follicular fluid was assayed for progesterone and oestradiol-17 $\beta$ so that the stage of development of the follicle could be assessed.

\section{Culture of granulosa cells}

The culture medium was Earle's balanced salt solution with the addition of $0.1 \mathrm{mg}$ sodium pyruvate $/ 100 \mathrm{ml}, 0 \cdot 75 \mathrm{~g}$ bovine serum albumin $/ 100 \mathrm{ml}$ and $100 \mathrm{i}$.u. penicillin $/ \mathrm{ml}$. Granulosa cells separated from follicular fluid were washed by suspension in culture medium and then centrifuged again. The endogenous concentrations of progesterone and oestradiol-17 $\beta$ in 3 samples of granulosa cells after washing did not exceed 8 and $5 \mathrm{ng}$ respectively.

The culture procedure followed was exactly that described by Fowler et al. (1978a). The cells were divided into two or three equal groups, as judged by microscopic examination of the size of the cell sheets in the aspirate, and placed in small tubes containing culture medium alone (controls) or medium with exogenous steroid substrate. All tubes were gassed with $5 \% \mathrm{CO}_{2}, 5 \% \mathrm{O}_{2}$, and $90 \% \mathrm{~N}_{2}$ and maintained at $37^{\circ} \mathrm{C}$ during the incubation period. The sheets of granulosa cells could not easily be dispersed, and cell counts were therefore made at the end of the culture period from squash preparations stained with methyl green. In the control tubes, the cells were suspended in $2.0 \mathrm{ml}$ medium and used to measure the production of steroids from endogenous substrate: $0.5 \mathrm{ml}$ was removed after 10 min to assess the concentration of steroids carried over from the follicular fluid at the beginning of culture. The cells in the other tubes were incubated with $1.5 \mathrm{ml}$ culture medium containing $17 \alpha-$ hydroxypregnenolone or DHA. The concentrations of exogenous substrate added to granulosa cell cultures (65-200 ng 17 $\alpha$-hydroxypregnenolone and 800-1250 ng DHA: see Table 1) were adjusted to be close to the range found in follicular fluid (Fowler, Chan, Edwards, Walters \& Steptoe, 1977). Samples of medium $(0.5 \mathrm{ml})$ were removed from all cultures after incubation for 3 and $10 \mathrm{~h}$. The production of various steroids was determined by subtracting the 10-min control value.

\section{Radioimmunoassay of steroids}

The radioimmunoassay procedures used were those described by Abraham, Hopper, Tulchinsky Swerdloff \& Odell (1971), Abraham, Buster, Kyle, Corrales \& Teller (1973), Abraham, Manlimos, Solis, Garza \& Maroulis (1975a) and Abraham, Manlimos, Solis \& Wickman (1975b). Six steroids (progesterone, 17 $\alpha$-hydroxyprogesterone, oestradiol-17 $\beta$, androstenedione, DHA and 17 $\alpha$-hydroxypregnenolone) were assayed in all samples of culture medium. Testosterone was assayed in medium from Follicles 1-6. Only progesterone and oestradiol-17 $\beta$ were assayed in follicular fluids. The specificities of the antisera, kindly supplied by Dr G. E. Abraham, were as described by Abraham et al. $(1971,1973,1975 \mathrm{a}, \mathrm{b})$.

After extraction of the samples with ether, the steroids were separated on Celite microcolumns by using a stationary phase of ethylene glycol (Abraham, Buster, Lucas, Corrales \& Teller, 1972). 
Triplicate measurements were used to establish the standard curves for each assay and the steroid concentrations were estimated in two samples of each follicular fluid and culture medium sample. The concentration of steroids in the sample was calculated by interpolation from the standard curve by using a non-linear asymptotic model which had been fitted to the curve by iterative methods (Walters, 1974). The mean of the 3 blank samples was subtracted from the steroid levels before correction for recovery, the blank values being consistently low $(<10 \mathrm{pg})$ in all assays. The measured values of known quantities of steroid added to the culture medium did not differ by more than $15 \%$ from the expected value. The smallest amount of steroid that could be measured per sample was $0.04 \mathrm{ng}$ for progesterone, $17 \alpha$-hydroxyprogesterone, androstenedione and testosterone, $0.03 \mathrm{ng}$ for oestradiol-17 $\beta$, and $0 \cdot 125 \mathrm{ng}$ for DHA and $17 \alpha$-hydroxypregnenolone. The precision of the assays was evaluated by duplicate measurements of the sample in the same or different assays. The average coefficient of variation ranged from 10.2 to $11.8 \%$ within assays and from 11.4 to $16.8 \%$ between assays.

\section{Urinary hormones}

\section{Results}

All 4 patients responded to treatment with $\mathrm{hMG}$; urinary oestrogen values increased to $\geqslant 200$ $\mu \mathrm{g} / 24 \mathrm{~h}$ (Text-fig. 1). Pregnanediol values remained low in Patient 1 , suggesting that luteinization had not occurred, but the rising levels of urinary pregnanediol ( $>6 \mathrm{mg} / 24 \mathrm{~h}$ ) in Patients 2,3 and 4 indicated that follicular luteinization had occurred in these women. There was no evidence of an endogenous LH surge before the hCG or LH injection except in Patient 2 in whom there was a rise in urinary LH on the day of hCG injection.
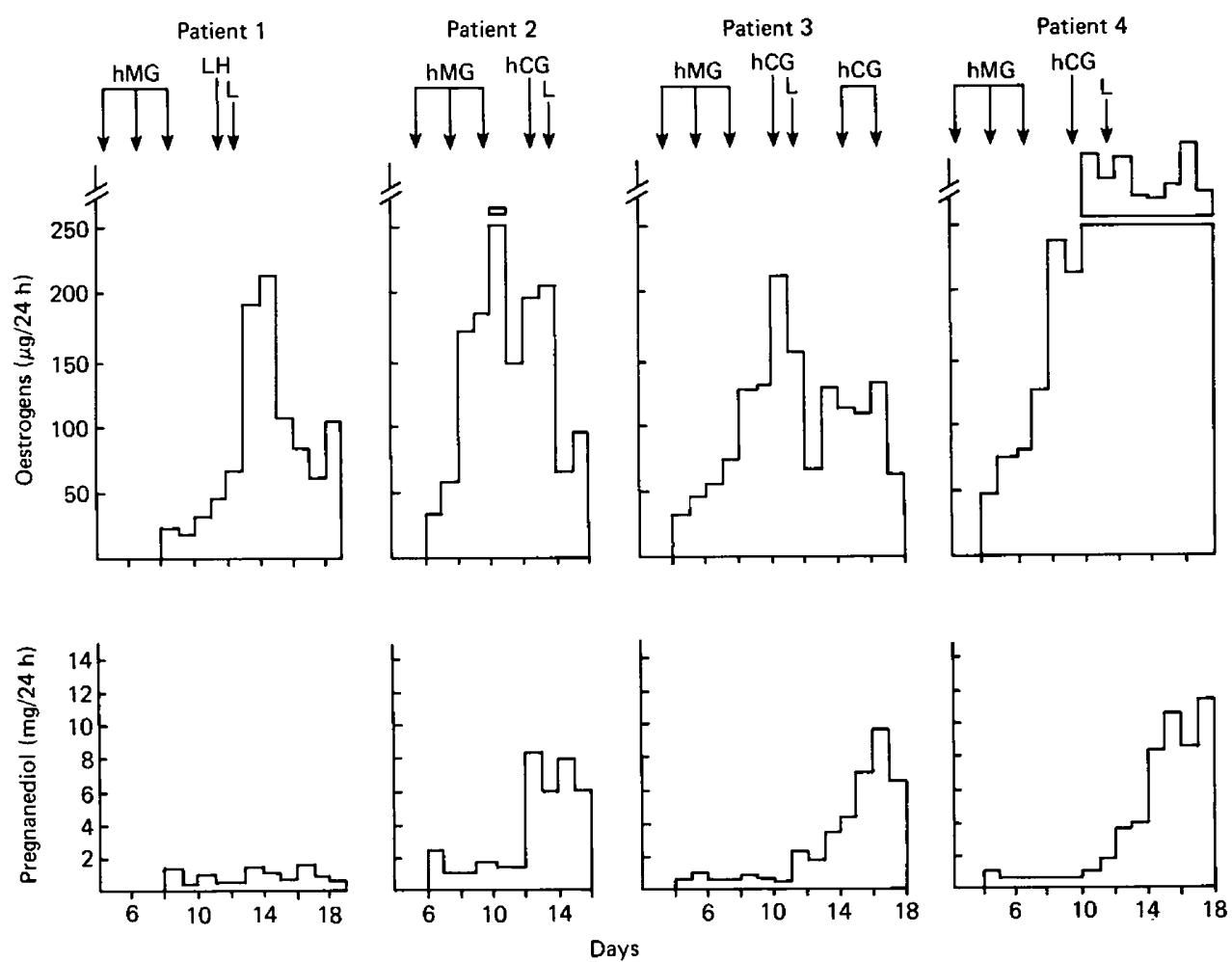

Text-fig. 1. Levels of urinary oestrogens and pregnanediol in the four patients treated with hMG and LH or hCG. $\mathrm{L}=$ time of laparoscopy. 
Ruth E. Fowler et al.

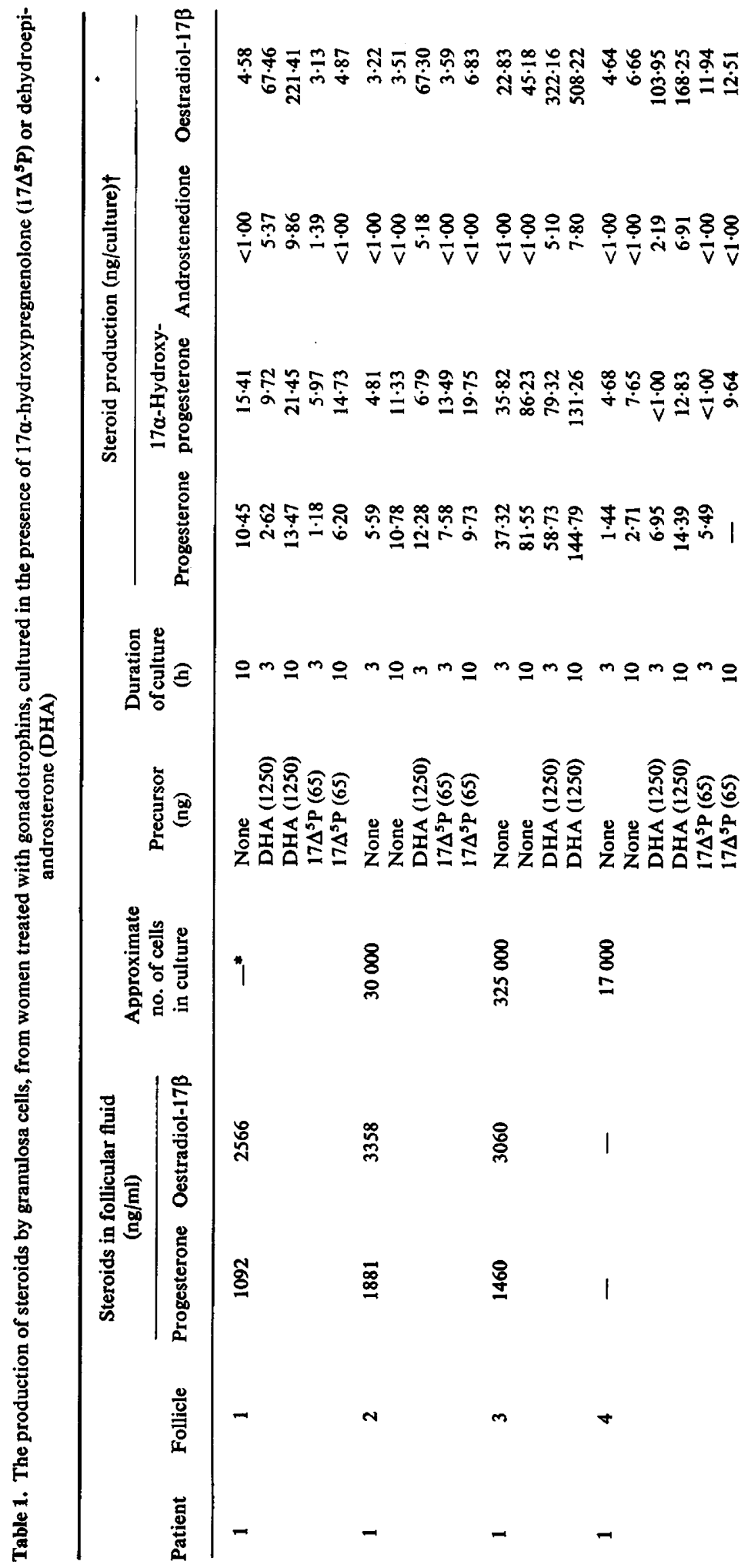




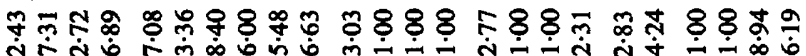

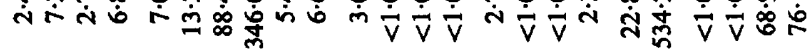

\&ุ\& \& \& \& \&

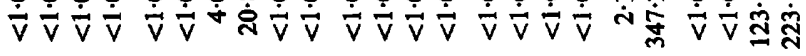

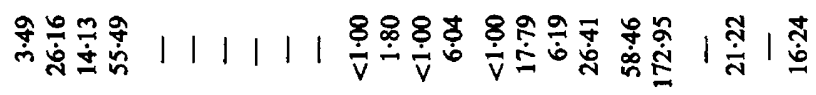

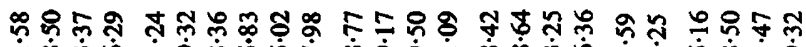

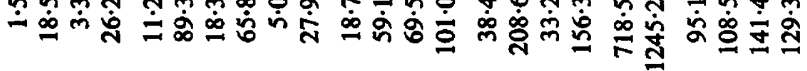

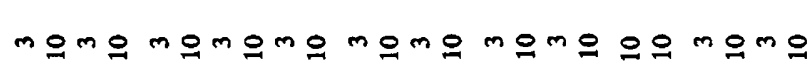

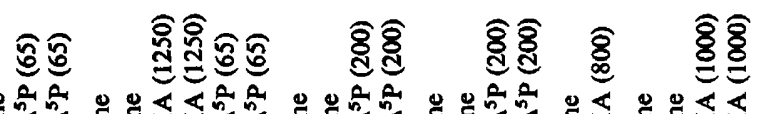

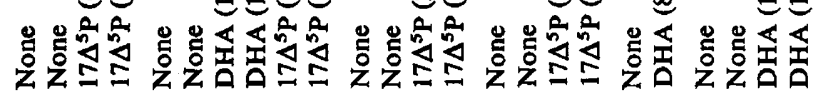

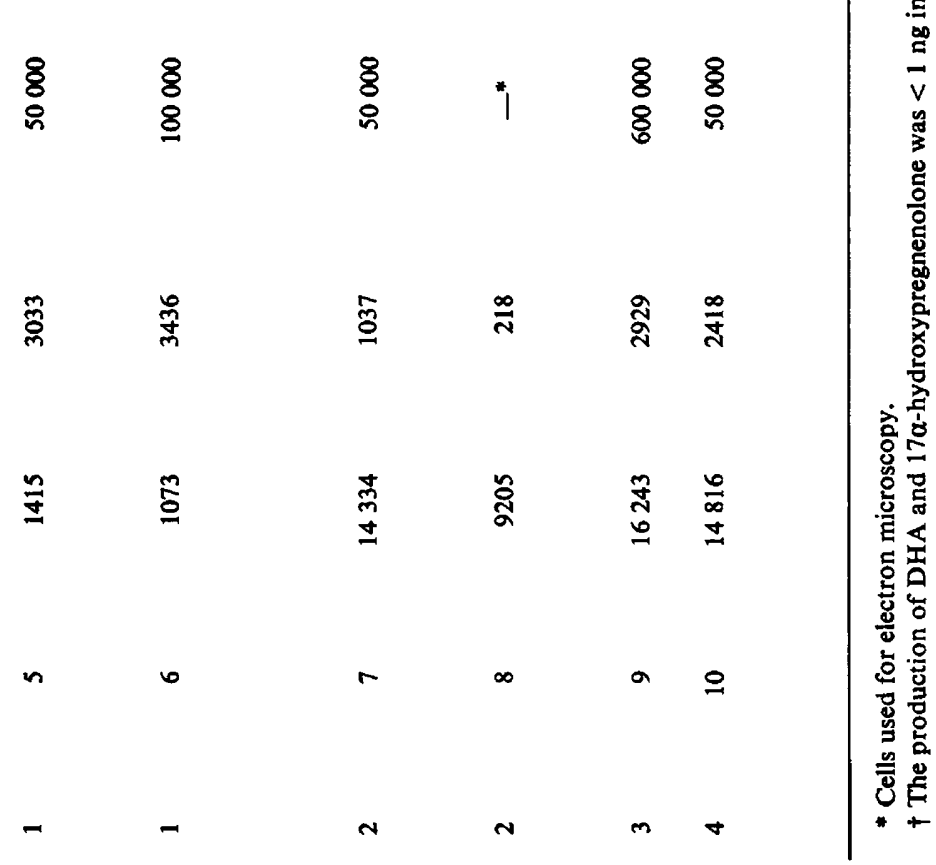




\section{Steroids in follicular fluid}

The concentration of progesterone in the fluid of follicles from Patients 2, 3 and 4 (Table 1) was very high, confirming that the follicles were preovulatory and that luteinization had evidently begun. The concentration of progesterone was much lower in the follicular fluid taken from Patient 1, again confirming that luteinization had not been induced. The concentration of oestradiol-17 $\beta$ in the follicular fluid of all but one of the follicles aspirated was high $(>1000 \mathrm{ng} / \mathrm{ml})$.

\section{Steroid production by granulosa cells}

Endogenous substrate. Very little progesterone was found in the control cultures of cells from Follicles 1-6 and this was especially evident when progesterone output was related to cell number (Tables 1 and 2). More progesterone was found in the cultures of granulosa cells from preovulatory follicles. Some 17 $\alpha$-hydroxyprogesterone was prociuced from endogenous substrate. In general, only small amounts of oestradiol-17 $\beta$ were present except for Follicles 3 and 9 , and the output per cell was lower from Follicles 8-10 than from Follicles 1-6.

Table 2. Mean (range in parentheses) cellular output (calculated from data in Table 1) of progesterone, oestradiol-17 $\beta$ and androstenedione by human granulosa cells cultured with dehydroepiandrosterone (DHA) or 17 $\alpha$-hydroxypregnenolone $\left(17 \Delta^{5} \mathrm{P}\right)$

\begin{tabular}{|c|c|c|c|c|c|}
\hline \multirow[b]{2}{*}{ Follicles } & \multirow{2}{*}{$\begin{array}{l}\text { Treatment } \\
\text { of patient }\end{array}$} & \multirow[b]{2}{*}{ Precursor } & \multicolumn{3}{|c|}{$\begin{array}{l}\text { Output of steroid in culture medium } \\
\left(\mathrm{ng} / 10^{3} \text { cells } / 10 \mathrm{~h} \text { incubation) }\right.\end{array}$} \\
\hline & & & Progesterone & Oestradiol-17 $\beta$ & Androstenedione \\
\hline \multirow{3}{*}{$1-6$} & \multirow{3}{*}{$h M G+L H$} & None & ${ }^{*} 0.40(0.16-0.89)$ & $+0.18(0.11-0.39)$ & 0.0 \\
\hline & & DHA & $0.65(0.45-0.85)$ & $\uparrow 4.26(1.56-9.90)$ & $0.20(0.02-0.41)$ \\
\hline & & $17 \Delta^{5} P$ & $0.37(0.27-0.53)$ & $0.30(0.13-0.72)$ & 0.0 \\
\hline \multirow{3}{*}{$8-10$} & \multirow{3}{*}{$h M G+h C G$} & None & $* 1.29(0.63-2 \cdot 17)$ & $0.01(0.0-0.04)$ & 0.0 \\
\hline & & DHA & $1.76(1.44-2.08)$ & $1.28(0.89-1.66)$ & $2.52(0.58-4.46)$ \\
\hline & & $17 \Delta^{5} \mathrm{P}$ & 2.02 & 0.0 & 0.0 \\
\hline
\end{tabular}

* Mean difference $( \pm$ s.e.m. $) 0.89 \pm 0.34(P<0.05)$.
t Mean difference $( \pm$ s.e.m. $) 4.08 \pm 1.66(P<0.05)$

Exogenous $D H A$. Substantial amounts of oestradiol-17 $\beta$ were produced in all incubations (Table 1), the output per cell being highest in cultures of cells from follicles that had not begun to luteinize (Follicles 1-6). Only small amounts of androstenedione and no testosterone were detected. The rate of conversion of DHA to androstenedione was presumably the factor that limited oestrogen production in these cultures. In contrast, androstenedione accumulated in cultures of cells from Follicles 9 and 10, probably because of incomplete aromatization, and this was reflected in the lower output of oestradiol-17 $\beta$ per cell (Table 2). Substantial quantities of DHA were utilized in all cultures (Table 3). It was not possible in this study to determine whether the addition of DHA to the culture medium affected progesterone output (see Hillier, Knazek \& Ross, 1977) because the availability of precursor would have been a limiting factor.

Exogenous 17 $\alpha$-hydroxypregnenolone. The production of progesterone and oestradiol-17 $\beta$ remained similar to that in control incubations (Tables 1 and 2). No androgens were produced. Little or no $17 \alpha$-hydroxypregnenolone was utilized during the incubation, although small amounts may have been converted to $17 \alpha$-hydroxyprogesterone (Table 3). Presumably, most $17 \alpha$-hydroxyprogesterone is formed from progesterone. 
Table 3. Utilization of dehydroepiandrosterone (DHA) and $17 \alpha$-hydroxypregnenolone (17 $\left.\Delta^{5} \mathrm{P}\right)$ and the production of androstenedione and oestradiol- $17 \beta$ by human granulosa cells aspirated from follicles $3-4 \mathrm{~h}$ before ovulation and cultured for $10 \mathrm{~h}$

\begin{tabular}{|c|c|c|c|c|c|c|}
\hline \multirow[b]{2}{*}{ Follicle } & \multicolumn{3}{|c|}{ Utilization of steroid* (ng) } & \multicolumn{3}{|c|}{ Production of steroid $\dagger(\mathrm{ng})$} \\
\hline & Substrate & $\begin{array}{c}\text { Amount } \\
\text { added }\end{array}$ & $\begin{array}{c}\text { Amount } \\
\text { utilized (\%) }\end{array}$ & Androstenedione & Oestradiol & $\begin{array}{l}\text { 17-Hydroxy- } \\
\text { progesterone }\end{array}$ \\
\hline 1 & & 65 & $11(17)$ & 2 & 5 & 15 \\
\hline 2 & & 65 & $19(29)$ & $<1$ & 5 & 20 \\
\hline 4 & & 65 & $2(3)$ & $<1$ & 13 & 10 \\
\hline 5 & $17 \Delta^{5} P$ & 65 & $2(3)$ & $<1$ & 7 & 56 \\
\hline 6 & & 65 & $11(17)$ & $<1$ & 7 & $\ldots$ \\
\hline 7 & & 200 & $0(0)$ & $<1$ & 1 & 6 \\
\hline 8 & & 200 & $0(0)$ & $<1$ & 2 & 26 \\
\hline 1 & & 1250 & $266(21)$ & 11 & 221 & \\
\hline 3 & & 1250 & $364(29)$ & 8 & 508 & \\
\hline 4 & & 1250 & $240(19)$ & 7 & 168 & \\
\hline 6 & DHA & 1250 & $660(53)$ & 21 & 346 & \\
\hline 9 & & 800 & $786(98)$ & 347 & 534 & \\
\hline 10 & & 1000 & $364(36)$ & 223 & 76 & \\
\hline
\end{tabular}

* Obtained by subtracting the amount of steroid present in the culture medium at the beginning from that present at the end of the incubation.

$\uparrow$ Obtained from data in Table 1.

\section{Discussion}

The type and pattern of steroid synthesis by granulosa cells in vitro will be conditioned by events in the follicle before aspiration. The increasing number of $\mathrm{LH}$ binding sites in growing follicles is associated with an increase in the ability of $\mathrm{LH}$ to stimulate adenylate cyclase activity and the production of cAMP (Ryan \& Lee, 1976; Channing \& Tsafriri, 1977). Previous exposure of the follicle to FSH and to $\mathrm{LH}$ is a prerequisite for follicular growth and surge levels of LH may be necessary for luteinization because monkey granulosa cells fail to luteinize in vitro if removed before the LH surge in vivo (Channing, 1970). In addition, the LH surge reduces aromatizing activity in the follicles of sheep (Moor, 1974) and rabbits (LeMaire \& Marsh, 1975) and the ovaries of rats (Katz \& Armstrong, 1976).

Two distinct pathways of steroid biosynthesis exist in human granulosa cells exposed to gonadotrophins. Pregnenolone is converted to progesterone and 17 $\alpha$-hydroxyprogesterone via the $\Delta^{4}$ pathway (Fowler et al., 1978a) and androgens are aromatized to oestradiol-17ß. However, $\Delta^{4}$ steroids are not converted to androgens, and pregnenolone and $17 \alpha$-hydroxypregnenolone are not metabolized to DHA or other androgens via the $\Delta^{5}$ pathway. The failure of granulosa cells to undertake these conversions may be due to the absence of the 17-hydroxylases and 17,20-lyases or to the inhibitory effects of steroids or other compounds in follicular fluid before the follicles were aspirated.

The two pathways of steroid synthesis by granulosa cells may be under independent control. Granulosa cells produce more progesterone from endogenous substrate as luteinization begins. $\mathrm{LH}$ may stimulate the production of pregnenolone from cholesterol (Hall \& Young, 1968), thus increasing the availability of precursor, or increase the $\Delta^{5} 3 \beta$-hydroxysteroid dehydrogenase/isomerase activity. The stimulation of the $\Delta^{4}$ pathway would lead to increasing amounts of progesterone in follicular fluid as ovulation approaches. In contrast, the aromatizing activity of granulosa cells declines as luteinization proceeds and large quantities of androstenedione are not aromatized in vitro. A decrease in oestradiol synthesis has been observed in the rat after the injection of LH and was accompanied by a decline in the activity of the aromatizing enzymes and possibly a limitation of available substrate (Katz \& Armstrong, 1976). DHA or other androgen precursors are presumably supplied by the thecal 
cells for aromatization in vivo, as proposed in the two-cell theory of oestrogen synthesis (Falck, 1959) and supported by studies on hamsters and sheep (Makris \& Ryan, 1975; Moor, 1977). The high concentrations of oestradiol-17 $\beta$ in follicular fluid are probably due to the aromatizing activity of granulosa cells.

The production of progesterone and the aromatization of androgens to oestrogens may occur in the same or in different granulosa cells, or granulosa cells may switch from the production of one steroid to another in response to changes in their steroid and gonadotrophin receptors.

We thank the Ford Foundation and the Thomas J. Watson Foundation (N.L.F.) for financial Support; Dr G. E. Abraham for so kindly providing all the antibodies used in this study; the Medical Research Council for the supply of human LH; Mrs Joan Baillie for technical assistance; and Miss Jean Purdy, Mr D. E. Walters, Professor C. R. Austin, Miss L. Howells and the Oldham and District Hospital Management Committee and the Manchester Regional Hospital Board for their help and encouragement.

\section{References}

Abraham, G.E., Hopper, K., Tulchinsky, D., SWerdloff, P.S. \& Odell, W.D. (1971) Simultaneous measurement of plasma progesterone, 17hydroxyprogesterone and oestradiol-17 $\beta$ by radioimmunoassay. Analytical Letters 4, 325-335.

Abraham, G.E., Buster, J.E., Lucas, L.A., Corrales, P.C. \& Teller, R.C. (1972) Chromatographic separation of steroid hormones for use in radioimmunoassay. Analytical Letters 5, 509-517.

Abraham, G.E., Buster, J.E., Kyle, F.W., Corrales, P.C. \& Teller, R.C. (1973) Radioimmunoassay of plasma pregnenolone, 17-hydroxypregnenolone, and dehydroepiandrosterone under various physiological conditions. J. clin. Endocr. Metab. 37, 140-144.

Abraham, G.E., Manlimos, F.S., Solis, M., Garza, R. \& MAROUlis, G.B. (1975a) Combined radioimmunoassay of four steroids in one $\mathrm{ml}$ of plasma. I. Progestins. Clin. Biochem. 8, 369-373.

Abraham, G.E., Manlimos, F.S., Solis, M. \& WickMAN, A.C. (1975b) Combined radioimmunoassay of four steroids in one $\mathrm{ml}$ of plasma. II. Androgens. Clin. Biochem. 8, 374-378.

Brown, J.B., Macleod, S.C., MacNaughton, C., Smith, M.A. \& SMYth, B. (1968) A rapid method for estimating oestrogens in urine using a semi-automatic extractor. $J$. Endocr. 42, 5-15.

Channing, C.P. (1969) Steroidogenesis and morphology of human ovarian cell types in tissue culture. $J$. Endocr. 45, 297-308.

Channing, C.P. (1970) Effects of stage of the menstrual cycle and gonadotrophins on luteinization of rhesus monkey granulosa cells in culture. Endocrinology 87, 49-60.

Channing, C.P. \& TsafriRi, A. (1977) Mechanism of action of luteinizing hormone and follicle-stimulating hormone on the ovary in vitro. Metabolism 26, 413-468.

Edwards, R.G. \& Steptoe, P.C. (1975) Induction of follicular growth, ovulation and luteinization in the human ovary. J. Reprod. Fert., Suppl. 22, 121-156.

FALCK, B. (1959) Site of production of oestrogen in rat ovary as studied in micro iransplants. Acta physiol. scand. 47, Suppl. 163, 94-101.
Fowler, R.E., Chan, S.T.H., WALTERS, D.E., EdWARDS, R.G. \& STEPTOE, P.C. (1977) Steroidogenesis in human follicles approaching ovulation as judged from assays of follicular fluid. $J$. Endocr. 72, 259-271.

Fowler, R.E., Fox, N.L., Edwards, R.G., Walters, D.E. \& Steptoe, P.C. (1978a) Steroidogenesis by cultured granulosa cells aspirated from human follicles using pregnenolone and androgens as precursors. J. Endocr. 77, 171-183.

Fowler, R.E., Edwards, R.G., Walters, D.E., Chan, S.T.H. \& Steptoe, P.C. (1978b) Steroidogenesis in preovulatory follicles of patients given HMG and HCG as judged by the radioimmunoassay of steroids in follicular fluid. J. Endocr. 77, 161-169.

Hall, P.F. \& Young, D.E. (1968) Site of action of trophic hormones upon the biosynthetic pathways to steroid hormones. Endocrinology 82, 559-568.

Hillier, S.G., KNAzeK, R.A. \& Ross, G.T. (1977) Androgenic stimulation of progesterone production by granulosa cells from preantral ovarian follicles. Further in vitro studies using replicate cell cultures. Endocrinology 100, 1539-1549.

KATZ, Y. \& ARMSTRONG, D.T. (1976) Inhibition of ovarian estradiol-17 $\beta$ secretion by luteinizing hormone in prepubertal, pregnant mare serum treated rats. Endocrinology 99, 1442-1447.

LEMAIRE, W.J. \& MARSH, J.M. (1975) Interrelationships between prostaglandins, cyclic AMP and steroids in ovulation. J. Reprod. Fert., Suppl. 22, 53-74.

MAKRIS, A. \& RYAN, K.J. (1975) Progesterone, androstenedione, testosterone, estrone and estradiol synthesis in hamster ovarian follicle cells. Endocrinology 96, 694-701.

Moor, R.M. (1974) The ovarian follicle of sheep: inhibition of oestrogen secretion by luteinizing hormone. J. Endocr. 61, 455-463.

Moor, R.M. (1977) Site of steroid production in ovine Graafian follicles in culture. $J$. Endocr. 73, 143150.

Rogers, M.A. \& Chamberlain, J. (1972) The use of the steroid analyser in conjunction with a semi-automatic gas chromatograph in the routine analysis of urinary pregnanediol. Clin. chim. Acta 39, 439-447. 
RYAN, R.J. \& LEE, C.Y. (1976) The role of membrane bound receptors. Biol. Reprod. 14, 16-29.

Ryan, K.J. \& PeTro, Z. (1966) Steroid biosynthesis by human ovarian granulosa and thecal cells. $J$. clin. Endocr. Metab. 26, 46-52.

Siddiqui, S.A., Jackson, L.S. \& Craig, A. (1975) A rapid assay for the determination of gonadotrophins in biological fluids. In Radioimmunoassay in Clinical
Biochemistry, pp. 225-324. Ed. C. A. Pasternak. Heyden, London.

WALTERS, D.E. (1974) The use of asymptotic models in multiple hormone assays. $n l R$. statist. Soc. $C 23$, 43-50.

YoungLai, E.V., Edwards, R.G. \& Steptoe, P.C. (1972) The enzymatic activity of aspirates of preovulatory human follicles. Can. J. Biochem. 50, 233-236.

Received 8 December 1977 